\title{
Sjögrens syndrom
}

\author{
Johan G. Brun ${ }^{1,2}$ og Roland Jonsson ${ }^{1,3}$ \\ 1) Revmatologisk avdeling, Haukeland universitetssykehus \\ 2) Seksjon for revmatologi, Institutt for indremedisin, Universitetet i Bergen \\ 3) Broegelmanns Forskningslaboratorium, Gades institutt, Universitetet i Bergen \\ Korrespondanse: Johan G. Brun, Revmatologisk avdeling, Haukeland universitetssykehus, 5021 Bergen \\ E-post: johan.brun@helse-bergen.no Telefon: 55975422 / 55975400
}

\section{ENGLISH SUMMARY}

Brun JG, Jonsson R. Sjögren's syndrome. Nor J Epidemiol 2008; 18 (1): 67-72.

\begin{abstract}
Sjögren's syndrome has been defined as a chronic inflammatory and lymphoproliferative disease with autoimmune features characterized by a progressive mononuclear cell infiltration of exocrine glands, notably the lacrimal and salivary glands (autoimmune exocrinopathy). Estimates of prevalence and incidence have varied widely according to case finding methods and criteria used. The recent American-European Consensus Group criteria has attained a wide acceptance internationally. According to these criteria the prevalence of Sjögren's syndrome is between $0.1-0.6 \%$, and the incidence between 3 and 6 per 100.000 per year. The female:male ratio is 9:1. In addition to gender, autoimmune disease among first degree relatives and previous births have been identified as risk factors. Large population-based prospective studies are needed to identify life style risk factors. There is no strong evidence for a specific genetic component in SS and therefore a need for national and international collaborative efforts on association studies in large patient populations. Except for an increased risk of non-Hodgkin lymphoma mortality is not increased. Some predisposing factors for lymphoma have been identified. Exocrine function is decreased but usually stable, except for pasients with intitially low salivary flow or high focus scores. Secondary Sjögren's syndrome may occur in $10-30 \%$ of patients with other inflammatory systemic diseases.
\end{abstract}

\section{INNLEDNING}

Sjögrens syndrom er antaglig den hyppigste autoimmune revmatiske systemsykdommen etter revmatoid artritt. Sykdommen kan forekomme alene (primær Sjögren) eller sekundært til annen systemsykdom. Sjögrens syndrom kan defineres som en kronisk inflammatorisk og lymfoproliferativ sykdom med autoimmune trekk, karakterisert ved progressiv mononuklær celleinfiltrasjon i eksokrine kjertler, særlig spytt- og tårekjertler (autoimmun eksokrinopati). De viktigste kliniske aspektene er tørre øyne (keratokonjunctivitis sicca) og munntørrhet (xerostomia) ${ }^{1}$.

\section{KLINISKE FORHOLD}

Pasientene har ofte en rekke andre symptomer relatert til tørrhet i slimhinner og hud, blant annet nasale skorper og neseblødning, heshet/taleproblemer, svelgbesvær, halitose, tannproblemer, redusert lukt- og smakssans, residiverende hevelser i parotiskjertler, tørrhoste og dyspareuni. I tillegg er det vanlig med ledd- og muskelsmerter, utmattelse ("fatigue") og uspesifikke perifere nevrologiske symptomer. Mindre hyppig forekommende kan man se ikke-erosive artritter, Raynauds fenomen, hudvaskulitter, lymfadenopati, serositt, pulmonal fibrose, sentralnervøse symptomer og renal tubulær acidose ${ }^{1-6}$. Komorbiditet $\mathrm{i}$ form av thyreoidealidelser er vanlig og kan forekomme hos opp mot en tredjedel av pasientene $e^{7,8}$.
Behandling omfatter forskjellige former for lokalbehandlig for å lette tørrhetssymptomer. Pilokarpin peroralt kan stimulere til økt spyttproduksjon. Pasienter med artralgi eller mild artritt kan behandles med ikke-steroide antiinflammatoriske midler og antimalariamidler, men utmattelse og myalgi som er typisk for Sjögren er vanligvis ikke påvirkelig av medikamentell behandling. Noen pasienter med høy inflammatorisk aktivitet og organaffeksjon kan behandles med immunmodulerende medikamenter og steroider, på samme måte som pasienter med systemisk lupus erythematosus ${ }^{9}$. Behandling med anti-TNF-midler har vært skuffende ${ }^{10,11}$, mens B-cellehemming med rituximab og behandling med interferon alfa har vist noe mer oppløftende resultater ${ }^{12-14}$.

\section{ETIOPATOGENESE}

Etiopatogenesen ved Sjögrens syndrom er sannsynligvis multifaktoriell. Det finnes en selektiv antaglig autoimmunt betinget skade på eksokrint kjertelvev (autoimmun eksokrinopati) ${ }^{1}$. Selv om T-lymfocytter utgjør den dominerende celletype i den lesjonen man finner i kjertelvevet, blir sykdommen ansett å være en B-lymfocyttdrevet autoimmun sykdom ${ }^{15}$, og det er påvist at B-celler produserer autoantistoffer lokalt i vevet $^{16}$. Hos circa en fjerdedel av pasientene har det blitt påvist organisert lymfoid vev (germinalsentra) i biopsi fra spyttkjertler ${ }^{17,18}$. Dette kan tenkes å ha betydning for senere utvikling av malign lymfoprolifera- 
sjon. Prospektive studier vil kunne avklare dette.

En rekke interleukiner er vist å ha sammenheng med Sjögren eller sykdomsmanifestasjoner ved Sjögren, og feilreguleringer her kan tenkes å bidra til utvikling av sykdom og selve sykdomsprosessen. En aktuell kandidat er B-celle aktiverende faktor (BAFF) der det er påvist oppregulering hos Sjögrenpasienter, noe som kan tenkes å hemme en naturlig utryddelse (apoptose) av autoreaktive B-celler ${ }^{19}$. Et aktivert interferonsystem kan også spille en mulig rolle ved patogenesen $^{20}$. Det er så langt ingen sterke holdepunkter for en spesifikk genetisk komponent i patogenesen ${ }^{9}$.

\section{Prevalens og insidens}

Sjögrens syndrom har en global utbredelse men lite er kjent vedrørende eventuelle regionale forskjeller. Det finnes ingen enkeltstående test eller undersøkelse som gir diagnosen og studier har derfor benyttet seg av klassifikasjonskriterier. En lang rekke slike kriterier har vært foreslått og brukt de siste 20-30 årene. Dette har medført store forskjeller i resultatene når det gjelder prevalens, alt etter om det har vært krav om objektive holdepunkt for eksokrin affeksjon og autoimmunitet eller ikke. Fra 2002 har de såkalte EuropeiskAmerikanske kriteriene (American-European Concensus Group Criteria) ${ }^{21}$ fått stort gjennomslag internasjonalt ${ }^{9}$, og blir vel ansett som veiledende i klinisk diagnostikk også. Disse kriteriene krever tilstedeværelse av enten positiv biopsi fra små spyttkjertler eller autoantistoff mot SSA (Ro) og/eller SSB (La) (Figur 1).

Det er stor overvekt av kvinner og forholdstallet er ofte angitt å være 9:1 ${ }^{1}$, noe som kan passe med flere epidemiologiske studier $^{22-24}$. Sjögrens syndrom forekommer $\mathrm{i}$ alle aldersgrupper men er sjelden hos barn og unge $e^{25,26}$. Opplysninger om sykdomsdebut mangler i de større epidemiologiske studiene men er i autoritative verk angitt å opptre hyppigst mellom 40 og 60 år, noe som bekreftes ved gjennomgang av forskjellige kliniske sjögrenmaterialer ${ }^{3,8,27,28}$. Det kan være lang latenstid mellom symptomdebut og diagnose ${ }^{5,22}$. Epidemiologiske studier frem til i dag ser ikke ut til å være store nok til å kunne angi sikre aldersspesifikke prevalensrater, men det er klart at forekomsten øker med alder ${ }^{29-31}$, noe som kan ha sammenheng med at tørrhetssymptomer øker med alder ${ }^{32}$.

Det er få egentlig populasjonsbaserte studier på prevalens og insidens av Sjögrens syndrom. Flere studier har identifisert pasienter ut fra sykehusregistre eller legepraksispopulasjoner og så ekstrapolert til bakgrunnsbefolkningen. Avhengig av hvilke kriteriesett som er brukt har tidligere prevalensestimat variert mellom $0,26 \%$ og $3,3 \%{ }^{24,30,33-37}$. I en stor norsk populasjonsbasert studie av to aldersgrupper ble prevalensen estimert til $0,22 \%$ (95\% konfidensintervall $0,15-0,32$ ) hos 40-44 år gamle og til 1,40\% (1,02-1,92) hos 71-74 år gamle ${ }^{29}$. Her var de reviderte Europeiske kriteriene fra 1996 brukt $^{38}$. Nyere epidemiologiske undersøkelser basert på de Europeisk-Amerikanske konsensuskriteriene viser gjennomgående lave estimater. En gresk studie basert på legedefinerte cases i en stor befolkning fant en prevalens på $0,09 \%(0,08-0,10)^{39}$. En annen større populasjonsbasert gresk studie fant en prevalens på $0,15 \%(0,09-0,21)^{23}$. Prevalensen ble estimert til å være mellom $<0,1 \%$ og $0,4 \%$ i en studie basert på casus fra to legepraksiser i England ${ }^{40}$. For de fleste av studiene referert ovenfor er det slik at det er stor overvekt av kvinner med Sjögren. Prevalenstallene i rene kvinnepopulasjoner ville altså ha vært opp mot det dobbelte. Dette eksemplifiseres godt i en tyrkisk populasjonsbasert studie av kun kvinner. Estimatet her var på $0,72(0,33-1,57) \%{ }^{41}$.

Når det gjelder insidens er det få studier. En slovensk undersøkelse som anvendte de reviderte Europeiske kriteriene fra $1996^{38}$ og en amerikansk undersøkelse ga begge en årlig insidensrate på 3,9 per $100.000^{22,42}$. Noe overraskende fant man høyere tall i en større gresk studie som anvendte de nyeste og strengere kriteriene. Estimatet her var på 5,3 (4,5-6,1) per 100.000 per år ${ }^{39}$.

Odds ratio for Sjögrens syndrom i en italiensk casecontrol studie var 7,4 (2,8-20,1) hvis det var førstegradsslektning med autoimmun sykdom, og hos kvinner var det også noe økt risiko knyttet til gjennomgått svangerskap med odds ratio på $2,1(1,0-4,4)^{43}$. Ut fra prevalenstallene er det også klart at kjønn utgjør en betydlig risiko når det gjelder å utvikle Sjögrens syndrom. Utover dette er det per i dag lite som er kjent når det gjelder risikofaktorer for å utvikle sykdommen. Genetiske studier har så langt ikke gitt noen klare assosiasjoner ${ }^{44}$. Undersøkelser med tanke på mikroorganismer særlig Epstein-Barr virus som disponerende faktor har heller ikke funnet overbevisende sammenhenger ${ }^{45}$. Når det gjelder andre miljøfaktorer som røyking, alkohol og kosthold savnes det store prospektive befolkningbaserte undersøkelser.

\section{MORTALITET OG KREFTRISIKO}

Sjögrenpasienter har økt risiko for non-Hodgkin lymfom, ofte av såkalt mukosa-assosiert lymfoid vev (MALT) type. Tidligere estimater ${ }^{46,47}$ på en mer enn 40 ganger økning av denne risikoen har antaglig vært for høye, i det en nyere stor registerbasert undersøkelse viste en standardisert insidensratio på 15,57 (7,77$27,85)^{48}$. Prediktive faktorer for lymfom ved Sjögren er hudvaskulitt/ palpabel purpura, lave verdier av komplementfaktorer C3 og C4, lymfopeni av typen CD4+ T-celler, og parotishevelse ved første undersøkelse ${ }^{48,49}$. Store svenske prospektive kohortstudier viser ingen øt mortalitet eller kreftrisiko generelt ${ }^{48,50}$.

Bortsett fra den økte lymfomrisikoen er prognosen med henblikk på mortalitet og alvorlig morbiditet relativt god. Når det gjelder eksokrin funksjon, spesielt spytt- og tåreproduksjon ser det ut til å være et stabilt forløp for de fleste ${ }^{51-53}$. Dette kan henge sammen med at det største tapet av funksjon antaglig skjer i et svært tidlig stadium av sykdommen ${ }^{54}$. En gruppe pasienter med lave utgangsverdier for salivaproduksjon og høy focusscore kan ha progredierende eksokrint funksjons- 
Figur 1. Europeisk-Amerikanske klassifikasjonskriterier for Sjögrens syndrom (American-European Concensus Group $\left(\right.$ Criteria $\left.^{21}\right)$. De seks detaljerte spørsmål om tørrhetssymptomer fra øyne og munn er ikke tatt med.

\section{Revised international classification criteria for Sjögren's syndrome}

I. Ocular symptoms: a positive response to at least one 3 questions.

II. Oral symptoms: a positive response to at least one of 3 questions.

III. Ocular signs - that is, objective evidence of ocular involvement defined as a positive result for at least one of the following two tests:

1. Schirmer's I test, performed without anaesthesia ( $\leq 5 \mathrm{~mm}$ in 5 minutes)

2. Rose bengal score or other ocular dye score ( $\geq 4$ according to van Bijsterveld's scoring system)

IV. Histopathology: In minor salivary glands (obtained through normal-appearing mucosa) focal lymphocytic sialoadenitis, evaluated by an expert histopathologist, with a focus score $1, \geq 1$, defined as a number of lymphocytic foci (which are adjacent to normal-appearing mucous acini and contain more than 50 lymphocytes) per $4 \mathrm{~mm}^{2}$ of glandular tissue

V. Salivary gland involvement: objective evidence of salivary gland involvement defined by a positive result for at least one of the following diagnostic tests:

1. Unstimulated whole salivary flow ( $\leq 1.5 \mathrm{ml}$ in 15 minutes)

2. Parotid sialography showing the presence of diffuse sialectasias (punctate, cavitary or destructive pattern), without evidence of obstruction in the major ducts

3. Salivary scintigraphy showing delayed uptake, reduced concentration and/or delayed excretion of tracer

VI. Autoantibodies: presence in the serum of the following autoantibodies:

1. Antibodies to Ro(SSA) or La(SSB) antigens, or both

\section{Revised rules for classification}

\section{For primary SS}

In patients without any potentially associated disease, primary SS may be defined as follows:

a. The presence of any 4 of the 6 items is indicative of primary SS, as long as either item IV (Histopathology) or VI (Serology) is positive

b. The presence of any 3 of the 4 objective criteria items (that is, items III, IV, V, VI)

c. The classification tree procedure* represents a valid alternative method for classification, although it should be more properly used in clinical-epidemiological survey

For secondary $S S$

In patients with a potentially associated disease (for instance, another well defined connective tissue disease), the presence of item I or item II plus any 2 from among items III, IV, and V may be considered as indicative of secondary SS

Exclusion criteria

- Past head and neck radiation treatment

- Hepatitis C infection

- Acquired immunodeficiency disease (AIDS)

- Pre-existing lymphoma

- Sarcoidosis

- Graft versus host disease

- Use of anticholinergic drugs (since a time shorter than 4-fold the half life of the drug)

*Ikke vist her.

tap også senere i sykdomsforløpet ${ }^{8}$, og det er mulig at også SSA (Ro) positivitet og lave komplementverdier kan være risikofaktorer for slik progresjon ${ }^{55}$.

\section{SEKUNDERT SJÖGRENS SYNDROM}

Sekundært Sjögrens syndrom forekommer ved annen systemsykdom som revmatoid artritt og systemisk lupus erythematosus. De diagnostiske kriteriene er angitt i Figur 1. Avhengig av metodikk ved kasusidentifisering og diagnostiske kriterier har forekomsten vært angitt å være fra omtrent $10 \%$ til $50 \%$ ved disse andre systemsykdommene ${ }^{56-61}$, men antaglig er virkelig prevalens i nedre halvdel av dette spekteret ${ }^{1}$. Den vanligste primære sykdommen er revmatoid artritt og her er forekomsten angitt å være mellom omtrent 10 $30 \%{ }^{59,62,63}$. Det vanskeligjør de epidemiologiske studiene at tørrhetssymptomer er vanlig i befolkningen og øker med alder ${ }^{29,30,32,33,35}$, og slike symptomer er også vanlige hos pasienter med systemsykdommer som revmatoid artritt ${ }^{64,65}$.

\section{KONKLUSJON}

Sammenfatningsvis ser det ut til at prevalens av Sjögrens syndrom definert ved de Europeisk-Amerikanske kriteriene er mellom 0,1-0,6\%, altså et sted mellom det som er kjent for systemisk lupus erythematosus og 
revmatoid artritt, og betydlig lavere enn en del av de tidligere estimatene som har vært basert på mindre strenge kriterier. Insidensen er antaglig mellom 3-6 per 100.000 per år. Bortsett fra økt risiko for lymfom er prognosen stort sett god og de fleste pasientene har et relativt stabilt forløp hva gjelder eksokrin funksjon, selv om de kan ha betydlige subjektive plager $i$ form av tørrhetssymptomer og ledd- og muskelsmerter og utmattelse. Det er behov for store gjerne prospektive befolkningsbaserte studier for nærmere kartlegging av epidemiologiske forhold og risikofaktorer. Siden det ikke er holdepunkt for en spesifikk arvelig komponent ved Sjögren er det behov for store pasientmaterialer for å kunne kartlegge eventuelle bidrag fra genetiske faktorer. Dette gjør det nødvendig med nasjonalt og internasjonalt samarbeide. Når det gjelder behandling er det håp om at nye biologiske midler kan være til nytte. I denne forbindelse trengs det utviklingsarbeid med hensyn til redskap som kan brukes til å bedømme sykdomsaktivitet og oppnåelse av behandlingsmål. Dette arbeidet har startet på europeisk basis ${ }^{66,67}$. Det er også behov for mer forskning på sekundær Sjögren, spesielt med tanke på forekomst og disponerende faktorer, og det kan godt være at kriteriene for tilstanden må videreutvikles. En stor gruppe pasienter har tørrhetsplager og gjerne redusert spytt- og tåreproduksjon men oppfyller ikke kriterier for Sjögrens syndrom i det de mangler autoantistoff og positive biopsifunn. Disse pasientene kan ha like store subjektive plager som Sjögrenpasientene ${ }^{2,68}$. Dette er også et område der det er behov for mer forskning.

\section{REFERANSER}

1. Jonsson R, Bowman S, Gordon TP. Sjögren's syndrome. In: Koopman WJ, Moreland LW, eds. Arthritis and Allied Conditions - A Textbook of Rheumatology. Philadelphia: Lippincott Williams \& Wilkins, 2005: 16811705.

2. Brun JG, Madland TM, Gjesdal CB, Bertelsen L-T. Sjögren's syndrome in an out-patient clinic: Classification of patients according to the preliminary European criteria and the proposed modified European criteria. Rheumatology 2002; 41: 301-4.

3. Pertovaara M, Pukkala E, Laippala P, Miettinen A, Pasternack A. A longitudinal cohort study of Finnish patients with primary Sjogren's syndrome: clinical, immunological, and epidemiological aspects. Ann Rheum Dis 2001; 60: 467-72.

4. Skopouli FN, Dafni U, Ioannidis JP, Moutsopoulos HM. Clinical evolution, and morbidity and mortality of primary Sjogren's syndrome. Semin Arthritis Rheum 2000; 29: 296-304.

5. Haga HJ, Rygh T, Jacobsen H, Johannessen AC, Mjanger O, Jonsson R. [Sjogren's syndrome. New diagnostic aspects]. Tidsskr Nor Lageforen 1997; 117: 2197-200.

6. Jacobsen H, Brun J, Johannesen AC, Kloster R, Rygh T, Jonsson R. Sjögren's syndrome in Bergen during a two-year period. ENT symptoms in Sjögren's syndrome. In: Olofsson J, ed. Transactions of the XXV Congress of the Scandinavian Oto-Laryngological Society, Bergen, August 12-15th, 1993. Bergen, Norway: University of Bergen, 2000: 333-7.

7. Hansen BU, Ericsson UB, Henricsson V, Larsson A, Manthorpe R, Warfvinge G. Autoimmune thyroiditis and primary Sjogren's syndrome: clinical and laboratory evidence of the coexistence of the two diseases. Clin Exp Rheumatol 1991; 9: 137-41.

8. Haldorsen K, Moen K, Jacobsen H, Jonsson R, Brun JG. Exocrine function in primary Sjogren's syndrome. Natural course and prognostic factors. Ann Rheum Dis 2007 Oct 26 [Epub ahead of print].

9. Jonsson R, Bolstad AI, Brokstad KA, Brun JG. Sjogren's syndrome - a plethora of clinical and immunological phenotypes with a complex genetic background. Ann N Y Acad Sci 2007; 1108: 433-47.

10. Mariette X, Ravaud P, Steinfeld S, Baron G, Goetz J, Hachulla E et al. Inefficacy of infliximab in primary Sjogren's syndrome: results of the randomized, controlled Trial of Remicade in Primary Sjogren's Syndrome (TRIPSS). Arthritis Rheum 2004; 50: 1270-6.

11. Sankar V, Brennan MT, Kok MR, Leakan RA, Smith JA, Manny J, Baum BJ, Pillemer SR. Etanercept in Sjogren's syndrome: a twelve-week randomized, double-blind, placebo-controlled pilot clinical trial. Arthritis Rheum 2004; 50: 2240-5.

12. Cummins MJ, Papas A, Kammer GM, Fox PC. Treatment of primary Sjogren's syndrome with low-dose human interferon alfa administered by the oromucosal route: combined phase III results. Arthritis Rheum 2003; 49: 585-93.

13. Pijpe J, van Imhoff GW, Spijkervet FK, Roodenburg JL, Wolbink GJ, Mansour K et al. Rituximab treatment in patients with primary Sjogren's syndrome: an open-label phase II study. Arthritis Rheum 2005; 52: $2740-50$.

14. Seror R, Sordet C, Guillevin L, Hachulla E, Masson C, Ittah M et al. Tolerance and efficacy of rituximab and changes in serum B cell biomarkers in patients with systemic complications of primary Sjogren's syndrome. Ann Rheum Dis 2007; 66: 351-7.

15. Jonsson R, Nginamau E, Szyszko E, Brokstad KA. Role of B cells in Sjogren's syndrome - from benign lymphoproliferation to overt malignancy. Front Biosci 2007; 12: 2159-70. 
16. Tengner P, Halse AK, Haga HJ, Jonsson R, Wahren-Herlenius M. Detection of anti-Ro/SSA and anti-La/SSB autoantibody-producing cells in salivary glands from patients with Sjogren's syndrome. Arthritis Rheum 1998; 41: $2238-48$.

17. Jonsson MV, Skarstein K, Jonsson R, Brun JG. Serological Implications of Germinal Center-like Structures in Primary Sjogren's Syndrome. J Rheumatol 2007; 34: 2044-9.

18. Jonsson MV, Szodoray P, Jellestad S, Jonsson R, Skarstein K. Association between circulating levels of the novel TNF family members APRIL and BAFF and lymphoid organization in primary Sjogren's syndrome. $J$ Clin Immunol 2005; 25: 189-201.

19. Szodoray P, Jellestad S, Alex P, Zhou T, Wilson PC, Centola M, Brun JG, Jonsson R. Programmed cell death of peripheral blood B cells determined by laser scanning cytometry in Sjogren's syndrome with a special emphasis on BAFF. J Clin Immunol 2004; 24: 600-11.

20. Bave U, Nordmark G, Lovgren T, Ronnelid J, Cajander S, Eloranta ML, Alm GV, Ronnblom L. Activation of the type I interferon system in primary Sjogren's syndrome: a possible etiopathogenic mechanism. Arthritis Rheum 2005; 52: 1185-95.

21. Vitali C, Bombardieri S, Jonsson R, Moutsopoulos HM, Alexander EL, Carsons SE et al. Classification criteria for Sjogren's syndrome: a revised version of the European criteria proposed by the AmericanEuropean Consensus Group. Ann Rheum Dis 2002; 61: 554-8.

22. Plesivcnik Novljan M, Rozman B, Hocevar A, Grmek M, Kveder T, Tomsic M. Incidence of primary Sjogren's syndrome in Slovenia. Ann Rheum Dis 2004; 63: 874-6.

23. Trontzas PI, Andrianakos AA. Sjogren's syndrome: a population based study of prevalence in Greece. The ESORDIG study. Ann Rheum Dis 2005; 64: 1240-1.

24. Miyasaka N. [Epidemiology and pathogenesis of Sjogren's syndrome]. Nippon Rinsho 1995; 53: 2367-70.

25. Fujikawa S, Okuni M. A nationwide surveillance study of rheumatic diseases among Japanese children. Acta Paediatr Jpn 1997; 39: 242-4.

26. Drosos AA, Tsiakou EK, Tsifetaki N, Politi EN, Siamopoulou-Mavridou A. Subgroups of primary Sjogren's syndrome. Sjogren's syndrome in male and paediatric Greek patients. Ann Rheum Dis 1997; 56: 333-5.

27. Garcia-Carrasco M, Siso A, Ramos-Casals M, Rosas J, de la Red G, Gil V et al. Raynaud's phenomenon in primary Sjogren's syndrome. Prevalence and clinical characteristics in a series of 320 patients. $J$ Rheumatol 2002; 29: 726-30.

28. Origuchi T, Kawasaki E, Ide A, Kamachi M, Tanaka F, Ida H et al. Correlation between interleukin 10 gene promoter region polymorphisms and clinical manifestations in Japanese patients with Sjogren's syndrome. Ann Rheum Dis 2003; 62: 1117-8.

29. Haugen AJ, Peen E, Hultén B, Johannessen AC, Brun JG, Halse AK, Haga HJ. Estimation of the prevalence of primary Sjögren's syndrome in two age-different community-based populations using two sets of classification criteria. The Hordaland Health Study. Scand J Rheumatol 2008; 37: 30-34.

30. Thomas E, Hay EM, Hajeer A, Silman AJ. Sjogren's syndrome: a community-based study of prevalence and impact. Br J Rheumatol 1998; 37: 1069-76.

31. Drosos AA, Andonopoulos AP, Costopoulos JS, Papadimitriou CS, Moutsopoulos HM. Prevalence of primary Sjogren's syndrome in an elderly population. Br J Rheumatol 1988; 27: 123-7.

32. Schein OD, Hochberg MC, Munoz B, Tielsch JM, Bandeen-Roche K, Provost T, Anhalt GJ, West S. Dry eye and dry mouth in the elderly: a population-based assessment. Arch Intern Med 1999; 159: 1359-63.

33. Bjerrum KB. Keratoconjunctivitis sicca and primary Sjogren's syndrome in a Danish population aged 30-60 years. Acta Ophthalmol Scand 1997; 75: 281-6.

34. Dafni UG, Tzioufas AG, Staikos P, Skopouli FN, Moutsopoulos HM. Prevalence of Sjogren's syndrome in a closed rural community. Ann Rheum Dis 1997; 56: 521-5.

35. Jacobsson LT, Axell TE, Hansen BU, Henricsson VJ, Larsson A, Lieberkind K, Lilja B, Manthorpe R. Dry eyes or mouth - an epidemiological study in Swedish adults, with special reference to primary Sjogren's syndrome. J Autoimmun 1989; 2: 521-7.

36. Tomsic M, Logar D, Grmek M, Perkovic T, Kveder T. Prevalence of Sjogren's syndrome in Slovenia. Rheumatology 1999; 38: 164-70.

37. Zhang NZ, Shi CS, Yao QP, Pan GX, Wang LL, Wen ZX, Li XC, Dong Y. Prevalence of primary Sjogren's syndrome in China. $J$ Rheumatol 1995; 22: 659-61.

38. Vitali C, Bombardieri S, Moutsopoulos HM, Coll J, Gerli R, Hatron PY et al. Assessment of the European classification criteria for Sjogren's syndrome in a series of clinically defined cases: results of a prospective multicentre study. The European Study Group on Diagnostic Criteria for Sjogren's Syndrome. Ann Rheum Dis 1996; 55: 116-21.

39. Alamanos Y, Tsifetaki N, Voulgari PV, Venetsanopoulou AI, Siozos C, Drosos AA. Epidemiology of primary Sjogren's syndrome in north-west Greece, 1982-2003. Rheumatology 2006; 45: 187-91.

40. Bowman SJ, Ibrahim GH, Holmes G, Hamburger J, Ainsworth JR. Estimating the prevalence among Caucasian women of primary Sjogren's syndrome in two general practices in Birmingham, UK. Scand J Rheumatol 2004; 33: 39-43. 
41. Kabasakal Y, Kitapcioglu G, Turk T, Oder G, Durusoy R, Mete N, Egrilmez S, Akalin T. The prevalence of Sjogren's syndrome in adult women. Scand J Rheumatol 2006; 35: 379-83.

42. Pillemer SR, Matteson EL, Jacobsson LT, Martens PB, Melton LJ, 3rd, O'Fallon WM, Fox PC. Incidence of physician-diagnosed primary Sjogren syndrome in residents of Olmsted County, Minnesota. Mayo Clin Proc 2001; 76: 593-9.

43. Priori R, Medda E, Conti F, Cassara EA, Sabbadini MG, Antonioli CM et al. Risk factors for Sjogren's syndrome: a case-control study. Clin Exp Rheumatol 2007; 25: 378-84.

44. Bolstad AI, Jonsson R. Genetic aspects of Sjogren's syndrome. Arthritis Res 2002; 4: 353-9.

45. James JA, Harley JB, Scofield RH. Role of viruses in systemic lupus erythematosus and Sjogren syndrome. Curr Opin Rheumatol 2001; 13: 370-6.

46. Kassan SS, Thomas TL, Moutsopoulos HM, Hoover R, Kimberly RP, Budman DR et al. Increased risk of lymphoma in sicca syndrome. Ann Intern Med 1978; 89: 888-92.

47. Lazarus MN, Robinson D, Mak V, Moller H, Isenberg DA. Incidence of cancer in a cohort of patients with primary Sjogren's syndrome. Rheumatology 2006; 45: 1012-5.

48. Theander E, Henriksson G, Ljungberg O, Mandl T, Manthorpe R, Jacobsson LT. Lymphoma and other malignancies in primary Sjogren's syndrome: a cohort study on cancer incidence and lymphoma predictors. Ann Rheum Dis 2006; 65: 796-803.

49. Ioannidis JP, Vassiliou VA, Moutsopoulos HM. Long-term risk of mortality and lymphoproliferative disease and predictive classification of primary Sjogren's syndrome. Arthritis Rheum 2002; 46: 741-7.

50. Theander E, Manthorpe R, Jacobsson LT. Mortality and causes of death in primary Sjogren's syndrome: a prospective cohort study. Arthritis Rheum 2004; 50: 1262-9.

51. Gannot G, Lancaster HE, Fox PC. Clinical course of primary Sjogren's syndrome: salivary, oral, and serologic aspects. J Rheumatol 2000; 27: 1905-9.

52. Jonsson R, Kroneld U, Backman K, Magnusson B, Tarkowski A. Progression of sialadenitis in Sjogren's syndrome. Br J Rheumatol 1993; 32: 578-81.

53. Kruize AA, van Bijsterveld OP, Hene RJ, de Wilde PC, Feltkamp TE, Kater L, Bijlsma JW. Long-term course of tear gland function in patients with keratoconjunctivitis sicca and Sjogren's syndrome. Br J Ophthalmol 1997; 81: 435-8.

54. Pijpe J, Kalk WW, Bootsma H, Spijkervet FK, Kallenberg CG, Vissink A. Progression of salivary gland dysfunction in patients with Sjogren's syndrome. Ann Rheum Dis 2007; 66: 107-12.

55. Theander E, Andersson SI, Manthorpe R, Jacobsson LT. Proposed core set of outcome measures in patients with primary Sjogren's syndrome: 5 year follow up. J Rheumatol 2005; 32: 1495-502.

56. Kobak S, Kobak AC, Kabasakal Y, Doganavsargil E. Sjogren's syndrome in patients with ankylosing spondylitis. Clin Rheumatol 2007; 26: 173-5.

57. Andonopoulos AP, Drosos AA, Skopouli FN, Moutsopoulos HM. Sjogren's syndrome in rheumatoid arthritis and progressive systemic sclerosis. A comparative study. Clin Exp Rheumatol 1989; 7: 203-5.

58. Andonopoulos AP, Skopouli FN, Dimou GS, Drosos AA, Moutsopoulos HM. Sjogren's syndrome in systemic lupus erythematosus. J Rheumatol 1990; 17: 201-4.

59. Brun JG, Jacobsen H, Kloster R, Cuida M, Johannesen AC, Hoyeraal HM, Jonsson R. Use of a sicca symptoms questionnaire for the identification of patients with Sjogren's syndrome in a heterogeneous hospital population with various rheumatic diseases. Clin Exp Rheumatol 1994; 12: 649-652.

60. Coll J, Rives A, Grino MC, Setoain J, Vivancos J, Balcells A. Prevalence of Sjogren's syndrome in autoimmune diseases. Ann Rheum Dis 1987; 46: 286-9.

61. Jonsson H, Nived O, Sturfelt G, Norberg R. Symptomatic secondary Sjogren's syndrome in patients with systemic lupus erythematosus (SLE). Relation to anti-SS-A and anti-SS-B autoantibodies. Scand J Rheumatol Suppl 1986; 61: 166-9.

62. Ericson S, Sundmark E. Studies on the sicca syndrome in patients with rheumatoid arthritis. Acta Rheumatol Scand 1970; 16: 60-80.

63. Uhlig T, Kvien TK, Jensen JL, Axell T. Sicca symptoms, saliva and tear production, and disease variables in 636 patients with rheumatoid arthritis. Ann Rheum Dis 1999; 58: 415-22.

64. Brun JG, Madland TM, Jonsson R. A prospective study of sicca symptoms in patients with rheumatoid arthritis. Arthritis Rheum 2003; 49: 187-92.

65. Jensen JL, Uhlig T, Kvien TK, Axell T. Characteristics of rheumatoid arthritis patients with self-reported sicca symptoms: evaluation of medical, salivary and oral parameters. Oral Dis 1997; 3: 254-61.

66. Stevens RJ, Hamburger J, Ainsworth JR, Holmes G, Bowman SJ. Flares of systemic disease in primary Sjogren's syndrome. Rheumatology 2005; 44: 402-3.

67. Vitali C, Palombi G, Baldini C, Benucci M, Bombardieri S, Covelli M et al. Sjogren's Syndrome Disease Damage Index and disease activity index: scoring systems for the assessment of disease damage and disease activity in Sjogren's syndrome, derived from an analysis of a cohort of Italian patients. Arthritis Rheum 2007; 56: 2223-31.

68. Gran JT, Myklebust G. Diagnostikk av primært Sjögrens syndrom. Tidsskr Nor Lageforen 2001; 121: 563-6. 